\title{
Economic Basics of Tourism
}

\section{Kaya Ngqaka}

Department of Economics, University of Pretoria

\begin{abstract}
This paper sets out to discuss the potential of tourism as a development instrument for underdeveloped economies. This is done by drawing on economic theory as well as evidence from the real world. While it is acknowledged that tourism development is one of the growth options for these countries, it is a policy often pursued against a background of a narrow resource base and serious balance of payments difficulties. However, only by observing sound economic principles can tourism be expected to achieve its economic goals.
\end{abstract}

JEL O 10

Tourism is perhaps the only sector of economic activity in which the principles of free trade still apply. More important, it is now possible for underdeveloped countries to improve their economies, not by increasing exports via low-cost production, but by tourism Naylon, quoted in Oppermann \& Chon, 1972: 16).

\section{INTRODUCTION}

The growth of international tourism during the second half of the twentieth century has been called "phenomenal"; for example, between 1960 and 1990 it was reportedly more than 600 per cent (Harrison, 1992:3). The upsurge in tourist numbers has moreover caused the study of tourism to develop into an independent specialism - Tourism Management - rather more rapidly than was the case with, say, the economics of agriculture or transport economics in the past. In the process, the close relation between tourism and basic economic principles, though never denied, has sometimes tended to shift into the background. Yet specialisation is at the base of economics and tourism alike.

The purpose of this paper is to make this basic relationship explicit, with particular reference to the goal of economic development. Given this bias, the frame of reference here is the developing rather than developed world, though Harrison (1992: 8) showed that, in 1989, the latter attracted 65 per cent of all 
revenue from tourism. Also, though the paper is concerned with international tourism, it may be noted that this is in fact often largely eclipsed by domestic tourism (Oja, 2001). Finally, the frequently used (World Tourism Organization) definition that a tourist is a "temporary visitor staying at least 24 hours in a country" seems rather inappropriate as it really refers to human mobility in general, not tourism in particular. A more meaningful definition is found in the New Oxford Dictionary of English, to the effect that tourism is "the commercial organization and operation of holidays and visits to places of interest". A tourist, then, is "a person who is travelling or visiting a place for pleasure", from whose point of view tourism is therefore a luxury good.

\section{ECONOMIC BASICS}

\subsection{National accounting}

The essential macroeconomic role of tourism is, at least in principle, captured by the national accounting equation $\mathrm{Y}=\mathrm{C}+\mathrm{I}+\mathrm{G}+(\mathrm{X}-\mathrm{Z})$, where $\mathrm{X}$ includes expenditure by foreign tourists, as one form of a country's export receipts. It is, of course, not an autonomous figure, but more than likely to be positively related to Z, the country's import payments. Harrison (1992: 60-61) gives the following example, with specific reference to economically developing countries (LDCs):

...tourism is a complex product of which developing countries only supply a part - primarily accommodation and some transportation, as well as goods and services supplied by such small-scale establishments as local shops and restaurants. Tourism retailing and much of the transportation used by tourists is supplied by firms based in industrialised countries. The costs and benefits that developing countries obtain from international tourism thus largely depend on contractual relationships between firms located in destination countries and those in the industrialised countries, from which most tourists originate.

Such export-import interdependence is not confined to tourism. For example, South Africa's pre-1970 policy of "import substitution" at times gave rise to additional import payments for the necessary capital goods, that actually exceeded the import payments saved by means of this policy (Brand, 1976: 173). 


\subsection{Regional economics}

Another, even more explicit, point of contact between tourism and economics may be found in regional economic analysis, in the form of a simple "gravity" model expressed in the following terms (Isard, 1960: 68):

$$
\begin{array}{rll}
M_{i j}=P_{j} / d_{i j} \cdot f\left(z_{i}\right) & \\
\text { where } M_{i j}= & \text { migration to destination } i \text { from source } j \\
f\left(z_{i}\right)= & \text { some function of } Z_{i} \text { which measures the attractive force of } \\
P_{j}= & \begin{array}{l}
\text { destination } i \\
d_{i j}
\end{array}= & \text { distance between source } j \text { and destination } i^{-}
\end{array}
$$

The advantage of this model is that the significance of both tourism and economics can now be measured in human numbers. Briefly put, the gain in human numbers of a region or country $i$ depends positively on an attractive force $Z$ and negatively on the distance $d$ that people must cover, which may be generally interpreted as the obstacles to be surmounted between source $j$ and destination $i$. Of paramount importance is the population $P$ at the source. In the present case, $P$ may represent the potential tourists from the economically developed countries (DCs) who are likely to be attracted by the sights to see in the developing countries (LDCs). Given the necessary statistics, the model lends itself to the analysis of both international and domestic tourism, though our present concern is only with the former.

\section{LINKS}

\subsection{Development}

Tourism is a major force in global trade and plays an important role in the social, cultural and economic development of both DCs and LDCs. Governments therefore often invest in infrastructure in order to promote tourism (Copeland, 1991). In the LDCs there has been, still is, considerable debate on how to promote tourism as part of their development strategy.

Most LDCs are beset by problems like low levels and uneven distribution of income and wealth, high rates of unemployment, small size of their domestic markets which tends to hamper industrial development, heavy reliance on agriculture for export eamings, and widespread foreign ownership of assets.

As has been pointed out by Mathieson and Wall (1982), a rapid injection of tourist expenditure and foreign investment into the LDCs can have a significant 
impact on the economy, more so than if the same sum of money were spent in the developed economies. Economic growth and development however requires LDCs to undergo radical economic transformation, for example, from a traditional agricultural economy to a modern industrial one. But, such transformation would normally require more capital and loans than the LDCs as the net exporters of primary products, can raise in order to finance it. The advocates of tourism therefore believe that tourism is in this case both relevant and necessary.

The idea of "sustainable development" is particularly relevant to any naturalresource based tourism development. The most straightforward and commonly used definition of it is given by the World Commission on Environment and Development (1987) in its so-called Brundtland report: "Sustainable development is development that meets the needs of the present without compromising the ability of future generations to meet their own needs." In other words, natural resource exploitation should take account of long-term effects, including those on future generations, since certain decisions taken in the present impose costs likely to be borne by future generations too. Butler, (in Briguglio 1996) again defines sustainable tourism development as: "tourism which is developed and maintained in an area (community, environment) in such a manner and at such a scale that it remains viable over an indefinite period and does not degrade or alter the environment (human and physical) in which it exists to such a degree that it prohibits the successful development and wellbeing of other activities and processes".

LDCs tend to have a high-income elasticity of demand for basic needs and lowincome elasticity for environmental protection. This is often because the majority of the population is at the margin of subsistence. Tourism development in these countries has often reflected these priorities. For example, Kenya's coastal tourism development has been characterised by high population growth and over-harvesting and excessive use of resources, for example, high demand for fish and prawns, sewage pollution, deforestation and shortage of fresh water (de Beer et al., 1997). This has led to the deterioration of the tourism industry. An environmentally based development which fails to take care of the environment itself is therefore clearly not sustainable (Tisdell, 1999).

At least the following requirements have to be met if tourism development is to be sustainable (Odendal \& Schoeman, 1990):

- Development should not disrupt ecological systems, over-exploit natural resources, or damage cultures and societies;

- Technology used should be appropriate to the needs, skills, training and finances of the people using it; and 
- Development should be based on the needs, efforts and ideals of the local community and ensure self-reliance.

However, a major problem with the concept of sustainable development is that it may take a long time to ascertain whether or not an activity is actually sustainable (Butler in Briguglio et al., 1996). For poor and uneducated communities in the LDCs, it is particularly difficult to make accurate predictions about the future of potential tourism projects. The position should naturally improve, as these communities become more affluent and better educated.

\subsection{Employment}

Since tourism is a labour-intensive industry, it creates a significant number of jobs fairly quickly, particularly for semi-skilled and unskilled workers. The jobs created are of a low-cost nature, compared to economic activities like manufacturing. Tourism is thus regarded as more efficient than many other industries in generating employment in a less developed region or country with limited opportunities for development (Ioannides, 1995). Tourism may therefore be viewed as an appropriate development strategy for LDCs, seeing that most have a combination of low income and labour in abundance.

Employment arising directly from tourism, such as hotel jobs, normally absorbs a relatively small number of local residents. Indirect employment is however likely to be created in other sectors of the economy that do not directly depend on tourism for their existence but are linked to it, for example, public transport, restaurants, bars and retail outlets, places of entertainment, as well as arts and crafts. Induced employment would then arise from a general increase in demand for goods and services as a result of increased tourist expenditure. According to Gamble (1989), in an employment survey conducted in Tunisia, in 1974, it was estimated that for every extra hotel bed, 5.2 jobs would be created, that is, 1.1 directly in hotels and restaurants, 1.4 indirectly in the supporting industries and 2.7 in investment-related construction.

According to Archer, cited in Harrison (1992), tourism in Bermuda was responsible for the direct employment of almost two thirds of the labour force in 1985. The Caribbean Tourism Organisation (CTO) in 1989 estimated that, on the basis of 1.19 jobs per hotel room, direct employment in accommodation establishments in the Caribbean, Bermuda included, amounted to 141000 people. It went on to estimate that the total number of jobs generated by tourist demand was approximately three times that number.

In a recent survey by the World Travel and Tourism Council (WTTC), quoted in South African Tourism (2001), it was shown that for every eight tourists visiting 
South Africa, one job is created directly in the tourism industry. For every 19 tourists visiting South Africa one job is created indirectly in other economic sectors. The number of jobs directly created in tourism from 1995 to 1998 in South Africa increased by 23 per cent. This shows that tourism has meaningful potential as a major contributor to employment and economic growth.

However, other authors claim that tourism's contribution to employment has been exaggerated. Bachmann (1988), cited in Harrison (1992), claims that in Kenya the tourism industry in 1979 employed 0.5 per cent of all Kenyan workers, that is, the modern sector contributed 32000 jobs and was indirectly responsible for another 25000 work opportunities. But though tourism created some jobs, in reality it did not resolve the regional unemployment problem, because quite a large number of unemployed people moved from other parts of Kenya to tourist centres like Malindi and Watamu, thus increasing the proportion of unemployed people in those areas.

Rodenburg cited in Harrison (1992), found that international hotels create more jobs than smaller local hotels, pay higher wages and eam more foreign exchange, but also import more, have fewer linkages with local infrastructure and provide few entrepreneurial opportunities to the local population. However, Mayer quoted in Harrison (1992) claims that in Thailand the locally-owned hotels are more successful than large internationally-owned hotels, as far as creating more jobs, income and government revenue are concerned.

\subsection{Miscellaneous}

Numerous other links between tourism and the economy exist as well, of which the following are briefly mentioned below: entrepreneurship, multiplier effect, economic structure and foreign exchange.

Entrepreneurship: Seeing that tourism has backward linkages, various external economies arise. This is, for example, evident in the construction of hotels, improvement of national as well as local transportation networks, and provision of water and electricity - all due to increasing demand in the tourism industry. However, according to Mathieson and Wall (1982), the establishment of linkages between the tourist sector and local entrepreneurs, depends on the following:

- The type of suppliers and producers with which the tourist industry's demands are linked.

- The capacity of local suppliers to meet these demands.

- The historical development of tourism in the destination area.

- The type of tourist development. 
Linkages stimulate demand for local products, but the effects of this may be constrained by outdated technology and increasing competition from foreign parties. It would therefore be commendable to reduce reliance on foreign agents and intensify links with local entrepreneurs, in order to maximise the positive effects of tourism development. This can, for example, be achieved by developing domestic Small, Medium and Micro Enterprises. Substantial financial support and training of local initiative in running suitable tourist enterprises in economically less developed regions therefore makes sense.

Multiplier effect: Pearce cited in Lea (1993: 41) defines the tourism multiplier effect as the way in which tourist spending filters through the economy, thereby stimulating other economic sectors too. The tourism multiplier can be more precisely defined as the ratio between the ultimate effect of tourist activity on the economy and the immediate expenditure by the tourists themselves (Curry in Johnson \& Barry, 1993). The initial benefits of tourism-related expenditure are thus amplified and spread through the domestic economy. The tourism industry has the potential to generate high multiplier effects, provided large leakages through imports can be avoided, for example, by promoting local industry.

Economic structure: It is likely that tourism development will be accompanied by other changes in the economic structure of tourism areas, like an increase in industrial production brought about by the increasing demand of the tourism industry. Many changes in economic structure are prompted by radical transformation from a primary producing economy (e.g. small-scale farming), to one characterised by tourism (e.g. construction of hotels and airports).

Foreign exchange: It emerged from section 2.1 above that receipts from international tourism are classified as export earnings. Tourism is in fact one of the five top export categories for 83 per cent of all countries and the main source of foreign currency for at least 38 per cent of them (World Trade Organization, 1998: 4).

COST AND RISK

\subsection{Overdependence}

Although tourism is a growth industry, it is vulnerable to many influences, such as price and income changes, political developments, the state of the economy, the availability of energy and seasonal factors. A decline in tourism demand due to a change in one or more of the above-mentioned variables in a particular destination area, may result in under-utilisation of resources and services, falling income and even loss of jobs to a greater or lesser extent. 
It is therefore important for a destination area not to depend entirely on tourism, seeing that it is subject to fluctuating demand. According to Mathieson and Wall (1982), these areas should try to promote diversity both within the tourist industry and the base economy. At the same time foreign ownership of the tourist resources should be kept at minimum, as this has some negative implications for the welfare of the local population. Moreover, tourism increases competition for land use, and consequently land prices are likely to increase in general.

\subsection{Cost}

Tourism involves various costs and is exposed to potentially devastating risks. Often overlooked are the opportunity costs of tourism; what benefits might the population have derived if the resources applied to tourism had been invested in another sector of the national economy? Then there are pecuniary supply costs (including maintenance) of tourist services, that range from the principal attractions themselves (e.g. game parks, natural sites, recreational facilities and resorts) to auxiliary services (e.g. accommodation, transport, tour guides).

The success of tourism itself may well give rise to additional costs and risks that impinge on supplier and tourist alike: pollution, congestion, environmental degradation, vandalism, crime, increased dropout rates from schools as children prefer jobs in the tourism industry to education, and so on. Above all, it is necessary to protect the "goose that lays the golden egg", in other words, to maintain intact the assets (both natural and man-made) which serve to draw the tourists in the first place.

\subsection{Risk}

The potential risks in the tourism industry are legion, for example: unrest and war, adverse climatic conditions, epidemics and natural disasters, and economic factors like recession and competition. All these are not only likely to lead to underutilised capacity, but loss of income and jobs as well.

\section{CONCLUSION}

In spite of the costs associated with it, tourism may well serve as a remedy for the sick economies of developing countries. Tourism can lead to economic growth and development, thus raising human living standards. As pointed out above, this may be achieved through the creation of employment and investment opportunities, also earning revenue for governments. Many different sectors of the economy are influenced by tourist expenditure and therefore benefit from it. 
The success story of countries like Spain, one of the developed countries today, can largely be attributed to tourism development. It is important for the LDCs to realise that they can in fact utilise assets that may have been regarded as "useless", for example, sun, beaches, untapped landscapes and other natural resources (i.e. eco-tourism) for export and profit.

Every kind of economic activity has its downsides, and these may be particularly deplorable, even repugnant, in tourism like alcohol misuse, drug trafficking and sexual abuse of children. But like money laundering, these are international problems that call for international countermeasures. Some success has already been achieved in this respect; European governments, in particular, now keep an eye on the behaviour of their nationals abroad.

Not only the points made in section 4 above, but the often seasonal nature of tourism call for expert management. Little wonder, then, that tourism has developed into an independent specialism. However, the economic considerations discussed here remain sine qua non.

\section{REFERENCES}

1 BRIGUGLIO, L. (1996) Sustainable Tourism in Islands and Small States, New York, St. Martins Press.

2 COPELAND, B.R. (1991) "Tourism, Welfare and De-industrialisation in a Small Open Economy", Economica,58: 515-29.

3 DE BEER,G.R.M., ELLIFFE, S.P., SPANGENBERG, P.P. \& WHEELER, B. (1997). "The Socio-Economic Impacts of Tourism-led Development The Case of the Kenyan Coastline from Malindi to Mombasa", Development Bank of Southern Africa - Specialist Business Unit, Johannesburg

4 GAMBLE, W.P. (1989) Tourism and Development in Africa: Case Studies in Developing Countries, London

5 HARRISON, D. (1992) Tourism and the Less Developed Countries, Great Britain, Belhaven Press.

6 ISARD, W. (1960) Methods of Regional Analysis: An introduction to Regional Science, Cambridge, The MIT Press.

7 JOHNSON, P. \& BARRY, T. (1993) Perspectives on Tourism Policy, Great Britain.

8 LEA, J. (1993) Tourism and Development in the third world, Great Britain, Rouledge.

9 MATHIESON, A. \& WALL, G. (1982) Tourism-Economics, Physical and Social impacts, United Kingdom, Longman. 
10 ODENDAL, A. \& SCHOEMAN, V. (1990) "Tourism and Rural Development in Maputoland: A Case Study of the Kosi Bay Area", Development Southern Africa, 7(2), 195-207.

11 OJA, M. (2001). http:/www postimees ee/april04200l/arvamus/Malloja.

12 OPPERMANN, M. and CHON, K. (1997) Tourism in Developing Countries, United Kingdom, Alden Press.

13 TISDELL, C. (1999) Biodiversity, Conservation and Sustainable Development, Cheltenham: Edward Elgar.

14 WORLD COMMISSION ON ENVIRONMENT AND DEVELOPMENT (1987) Our Common Future, New York, Oxford University Press.

15 WORLD TOURISM ORGANIZATION (2000) www,worldtourism.org:83/omt/wtich.htm..

16 WORLD TRADE ORGANIZATION (1998) http://www.wto.org/english/traptop_e/serv e/w51.doc. 